\title{
A new late Carboniferous calamitacean sphenophyte from South Wales, United Kingdom
}

\author{
Christopher J. CLEAL ${ }^{1 *}$ \& Cedric H. SHUTE ${ }^{2}$
}

${ }^{1}$ Department of Natural Sciences, National Museum Wales, Cathays Park, Cardiff CF10 3NP, UK; chris.cleal@museumwales.ac.uk

${ }^{2}$ Department of Earth Sciences, The Natural History Museum, Cromwell Road, London SW7 5BD, UK; cedric.shute@gmail.com

* Corresponding author

Cleal, C.J. \& Shute, C.H. 2016. A new late Carboniferous calamitacean sphenophyte from South Wales, United Kingdom. [Una nueva esfenofita calamitacea del Carbonífero terminal del Sur de Gales, Reino Unido]. Spanish Journal of Palaeontology, $31(1), 25-40$.

\section{ABSTRACT}

A new calamitacean sphenophyte is described from the middle Westphalian coal-bearing strata of South Wales: Asterophyllites tayloriorum sp. nov. (leafy shoots) and Palaeostachya wagneri sp. nov. (cone-bearing shoots). Both the leafy shoots and cones are characterised by relatively small leaves/bracts in whorls of four. Although the leafy and cone-bearing shoots occur in close association, and were almost certainly parts of the same parent plant species, the case is made for assigning them to separate fossil-taxa.

Keywords: Palaeobotany, Equisetopsida, Carboniferous.

\section{RESUMEN}

Se describe una nueva esfenofita calamitacea del Westfaliense medio del Sur de Gales: Asterophyllites tayloriorum sp. nov. (tallos con hojas) y Palaeostachya wagneri sp. nov. (estróbilos). Tanto las hojas como los estróbilos están caracterizados por hojas/brácteas relativamente pequeñas en verticilos de cuatro. Aunque las hojas y estróbilos aparecen en asociación y son, casi con total certeza, parte de una misma especie vegetal, se argumenta por qué se asignan a taxones diferentes.

Palabras clave: Paleobotánica, Equisetopsida, Carbonífero. 


\section{INTRODUCTION}

The Equisetopsida (sometimes alternatively named Sphenopsida) is a class of ancient tracheophytes (vascular plants) that originated in Devonian times (Cleal, 1993). They are currently regarded as a basal group within the "Monilophyte clade" (i.e., the ferns, horsetails and whisk ferns) (e.g., Christenhusz \& Chase, 2014; Knie et al., 2015). In post-Palaeozoic floras by far the most widely found equisetopsids compare closely with the living genus Equisetum Linnaeus (e.g., Harris, 1961; Watson, 1983) which is characterised by usually stiff, photosynthetic stems, leaves that form a sheaf that is closely adpressed to the stem and which are often non-photosynthetic, and cones that lack bracts. These are assigned to the family Equisetaceae. In Palaeozoic floras, especially those of the tropical floras associated with coal deposits, the Equisetopsida is represented by rather different plants that had rather different foliage and cones, and are normally assigned to a separate family, for which the correct name is Calamitaceae.

Adpression fossils of the Calamitaceae are widespread in the Carboniferous coal-bearing deposits of Euramerica, including stems, roots, foliage and cones (e.g., Stur, 1887; Jongmans, 1911; Nĕmejc, 1953; Abbott, 1958, 1968; Gothan et al., 1959; Boureau, 1964; Crookall, 1969; Serret \& Brousmiche, 1987; Bek \& Opluštil, 1998; Barthel, 2004). Separate fossil-taxa (sensu Cleal \& Thomas, 2010; McNeill et al., 2012) are widely used for the different plant parts, but each on their own has often proved problematic for understanding the systematics of this group. Fossilspecies for stems are mainly defined on characters such as branch scars that reflect the overall architecture of the plant (Crookall, 1969) but it is unclear how this relates to the taxonomy of the original plants. The foliage is relatively simple both morphologically and (where preserved) in epidermal anatomy (e.g., Walton, 1936; Abbott, 1958), and so there are relatively few taxonomically useful characters available. The cones are more complex structures but much of that structure is often obscured during compression and fossilisation (e.g., Gastaldo, 1981a, b). Moreover, unlike in the Palaeozoic arborescent Lycopsida (e.g., Thomas, 1987) in situ spores derived from the cones have not proved particularly useful taxonomically (Serret \& Brousmiche, 1987; Bek \& Opluštil, 1998). The fossil-taxa for the cone adpressions have, therefore, tended to be based on characters such as cone size, shape, and bract shape and spacing, which would probably be regarded as less than reliable for recognising botanical, whole-plant species.

In the present paper, we document a well-preserved assemblage of specimens from South Wales, UK, representing foliage and cones of a previously undescribed type of Carboniferous equisetopsid. We have followed the currently accepted taxonomic convention and assigned the vegetative and cone-bearing shoots to separate fossil- taxa, even when (as in the present case) there is strong circumstantial evidence that they were originally parts of the same biological taxon. We will discuss the reasons for doing this later in the paper.

\section{MATERIALS AND METHODS}

The fossils described in the paper form part of the Cliff and Iris Taylor Collection in the Department of Earth Sciences, the Natural History Museum, London. This extensive collection of plant fossils was from a large spoil-tip at Hirwaen, near Ebbw Wales, south Wales, UK (Fig. 1). As they are from a spoil tip, it is not certain exactly what stratigraphical level they originated from, but most of the mines in this area were working coals from the South Wales Middle Coal Measures Formation (middle Westphalian Stage - upper Bashkirian Stage). The descriptions are mainly based on 10 vegetative shoots and 6 cone-bearing shoots.

The fossils are preserved in a medium-grey laminated mudstone and are highly coalified. This coalification makes the fossils highly reflective, but the morphology is clearly revealed by using cross-polar illumination (Crabb, 2001). Two of the cones were prepared using the Transfer technique (Walton, 1923; for a historical review see Escapa et al., 2010), thus revealing anatomical detail such as the arrangement and attachment of the sporangiophores.

\section{TAXONOMIC AND NOMENCLATURAL REMARKS}

\subsection{Family taxonomy}

The late Carboniferous (Pennsylvanian) sphenophytes from the palaeotropical Euramerican floras are usually assigned to a different family to the extant plants based mainly on the foliage consisting of quite clearly developed photosynthetic leaf whorls that were not adpressed to the stem, and cones in which the whorls of sporangiophores were separated by whorls of sterile bracts (e.g., GrauvogelStamm \& Lugardon, 2009; Thomas, 2014). Meyen (1978, 1987) argued that the correct name for this Pennsylvanian family is Calamostachyaceae: his argument was that families of fossil plants should be based of fossil-genera of reproductive structures, as it is only the type of such a fossil-genus that can be definitely included within the circumscription of a family. However, this procedure does not follow the regulations in the International Code of 


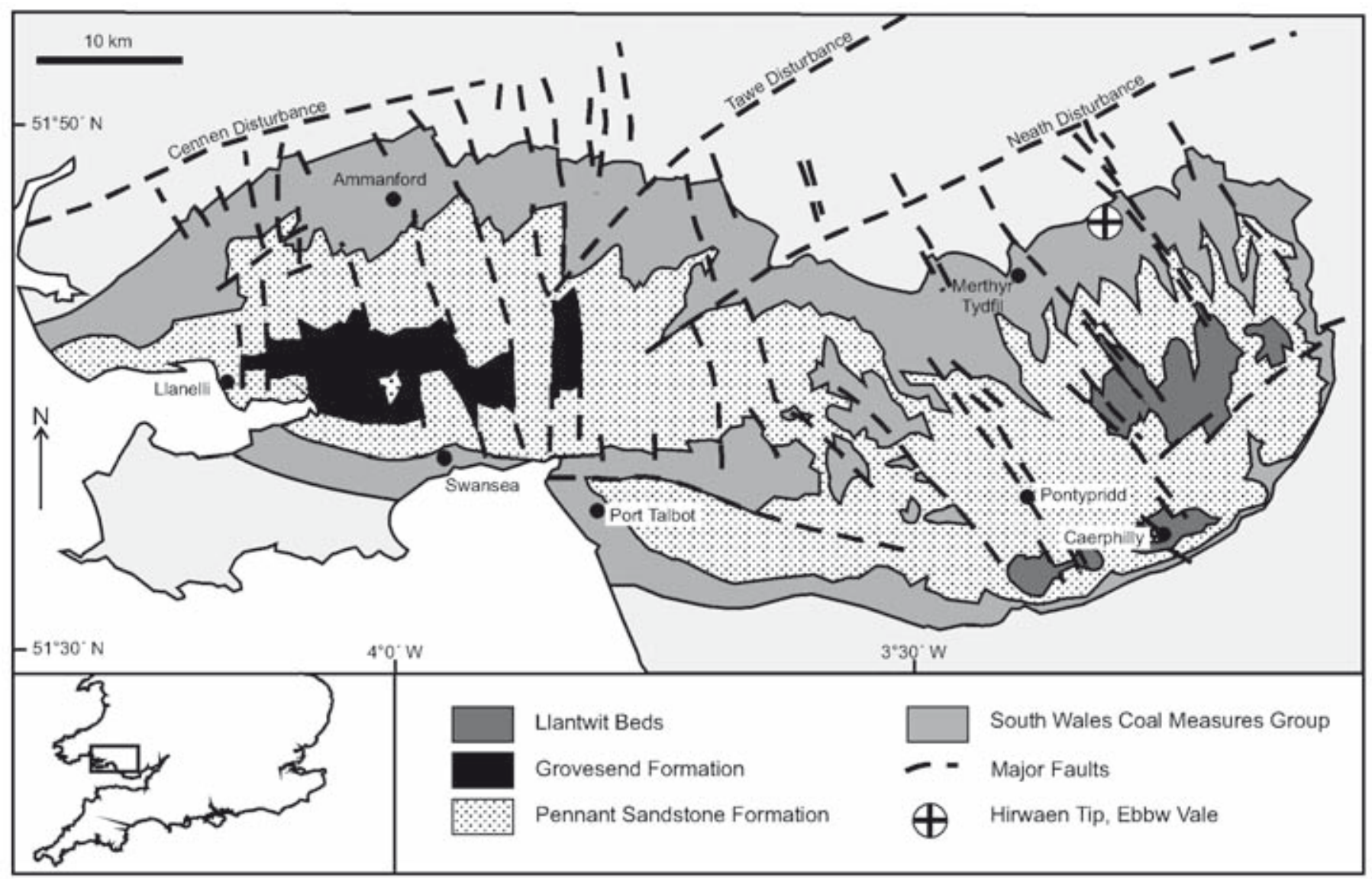

Figure 1. Geological map of the South Wales Coalfield, showing the location of the Hirawen Tip near Ebbw Vale. Adapted from Cleal (2007).

Nomenclature for algae, fungi, and plants (ICN - McNeill et al., 2012); the correct name is the earliest published one for which the type belongs to that family, no matter what part of the plant that type originated from. In this case, there is a strong argument that the much earlier published Calamitaceae Unger, 1840 is the correct name, the type of which is the type of Calamites suckowii Brongniart, $1828 \mathrm{~b}$ (see Cleal et al., 2012a). Although the latter is a stem pith cast, it is generally acknowledged that it belonged to the same group of Palaeozoic equisetopsids as Meyen $(1978,1987)$ was calling Calamostachyaceae; there are no other families normally recognised for these Palaeozoic equisetopsids to which it could belong.

\subsection{Generic taxonomy (foliage)}

The most thorough taxonomic analyses of these foliage fossil-genera have been by Jongmans $(1911,1914)$, Abbott (1958), Boureau (1964) and Crookall (1969). Such foliage tends to be assigned to one of two fossilgenera: Asterophyllites Brongniart, 1828a nom. cons. and Annularia Sternberg, 1821. Conventionally, the genera have been separated based on the general shape and orientation of the leaves: Asterophyllites tends to have smaller, more slender, linear leaves that arch towards the shoot apex (acroscopically) to form cup-like whorls around the stem; and Annularia has generally larger, lanceolate or spathulate leaves that tend to be arranged in more or less flat whorls that may lie either at rightangles or at an angle to the stem. A third fossil-genus, Phyllotheca Brongniart, 1828a has occasionally been used for Annularia-like whorls of leaves that are basally fused to form a distinct collar around the stem (e.g., Zeiller, $1896,1899)$ but generally such fossils are assigned to Annularia. In the fossils documented in this paper, the leaves are relatively small and curve acroscopically in a cup-shaped configuration around the stem, and so clearly correspond to Asterophyllites.

The early taxonomic nomenclature of Asterophyllites was considerably confused: the type of the name (Asterophyllites radiatus Brongniart, 1822) is now regarded as belonging to Annularia (e.g., Jongmans, 1911, 1914), and there were several other generic names published at about the same time that could potentially compete with it for priority, notably Schlotheimia Sternberg, 1821, Bornia Sternberg, 1825, Bechera Sternberg, 1825 and Bruckmannia Sternberg, 1825. The confusion was 
eventually resolved by Vogellehner (1967) who formally proposed that Asterophyllites Brongniart, 1828a (with the type Asterophyllites equisetiformis (Sternberg, 1825) Brongniart, 1828a) should be conserved over Asterophyllites Brongniart, 1822 and the four Sternberg generic names; this situation still stands in the current $I C N$ (McNeil et al., 2012).

The name Calamocladus Schimper, 1869 was introduced for branches and leafy shoots of plants with Calamites stems, Asterophyllites being retained for morphologically comparable shoots but whose affinities are uncertain. A number of authors accepted this nomenclature (e.g., Seward, 1898; Thomas, 1910, 1911) but it overlooked the fact that both the original type (Asterophyllites radiatus) and the species most authors have taken to be the types and is now conserved as such (Asterophyllites equisetiformis) are undoubtedly leafy shoots borne by Calamites stems. Calamocladus must therefore be regarded as an illegitimate later taxonomic synonym of Asterophyllites.

\subsection{Generic taxonomy (cones)}

The reproductive structures of Pennsylvanian-age sphenophytes are oblong-cylindrical cones consisting of alternating whorls of simple or sometimes partly fused bracts, and peltate sporangiophores each bearing usually four (sometimes fewer) sporangia (Taylor et al., 2009); the presence of these bracts is one of the key features that distinguish these Palaeozoic plants from the extant sphenophytes. The cones are mostly homosporous with spores belonging to the dispersed spore genera Calamospora or (if the elaters are still preserved intact) Elaterites; but some are heterosporous (e.g., Hartung, 1933; Thomas, 1969), and one has been described where each megasporangium has only one megaspore (Baxter, 1963; see also comments by Bateman \& DiMichele, 1994). The cones were normally borne in shoots, as in the Welsh specimens (although there were some exceptions to this e.g., Thomas, 1969; Rößler \& Thiele-Bourcier, 1999) but where these shoots were on the plant is not certain.

A number of fossil-genera have been distinguished based mainly on the form of the bracts, and the relationship between the bracts and sporangiophores. Although there have been fossil-genera created specifically for anatomically-preserved cones defined by characters that are difficult or impossible to observe in adpressions (e.g., Calamocarpon Baxter, 1963, Weissistachys Rothwell \& Taylor, 1971, Pendulostachys Good, 1975; see discussion by Gastaldo, 1981b) mostly the same fossil-genera are used for cones in both modes of preservation. Reviews of the generic classification of these cones have been given by Jongmans (1911), Kosanke (1955), Good (1975) and Gastaldo (1981b). The seven most widely used fossil-genera used for cone adpressions and authigenic mineralisations are summarised in Table 1. In addition, there are the fossil-genera Paracalamostachys Weiss, 1884 and Macrostachya Schimper, 1869, used for relatively small (Calamostachys/Palaeostachya - like) and relatively large sphenophyte cones where the attachment of the sporangiophores is unknown.

Table 1. Main diagnostic criteria for distinguishing the fossilgenera of calamstachyacean cone adpressions and authigenic mineralisations.

\begin{tabular}{lllc}
\hline & $\begin{array}{c}\text { Sporangiophore } \\
\text { attachment }\end{array}$ & Bracts & $\begin{array}{c}\text { Sporangia per } \\
\text { sporangiophore }\end{array}$ \\
\hline $\begin{array}{l}\text { Calamostachys } \\
\text { Schimper, 1869 }\end{array}$ & $\begin{array}{l}\text { Midway between } \\
\text { bract whorls }\end{array}$ & Slender & 4 \\
$\begin{array}{l}\text { Schimperia } \text { Remy \& } \\
\text { Remy, 1975 }\end{array}$ & $\begin{array}{l}\text { Midway between } \\
\text { bract whorls }\end{array}$ & Slender & 4 \\
$\begin{array}{l}\text { Palaeostachya } \\
\text { Weiss, 1876 }\end{array}$ & Axillary to bract & Slender & 4 \\
$\begin{array}{l}\text { Huttonia } \text { Sternberg, } \\
1837\end{array}$ & $\begin{array}{l}\text { Axillary to bract } \\
\text { Metacalamostachys }\end{array}$ & $\begin{array}{l}\text { Basally } \\
\text { fused }\end{array}$ & 1 \\
Hirmer, 1927 & bracts & & 1 \\
$\begin{array}{l}\text { Mazostachys } \\
\text { Kosanke, 1955 }\end{array}$ & $\begin{array}{l}\text { Directly below } \\
\text { bracts }\end{array}$ & Slender & 2 \\
$\begin{array}{l}\text { Cingularia Weiss, } \\
1869\end{array}$ & $\begin{array}{l}\text { Directly below } \\
\text { bracts }\end{array}$ & Blade-like & 4 \\
\hline
\end{tabular}

Although the diagnostic characters used to distinguish these fossil-genera appear clear-cut, they are not, in particular the position of attachment of the sporangiophores. Good (1975) and Remy \& Remy (1975) have shown that the position of attachment of the sporangiophores is not dependent on where the vascular strand is emitted from the cone axis. For instance, Remy \& Remy (1975) showed that in type Calamostachys, the sporangiophores are attached midway between the bract whorls, but the vascular strand is emitted from the bract axil as in Palaeostachya; for those cones where the vascular strand is actually emitted from the cone axis between the bract whorls, they established a new genus, Schimperia. They moreover showed that within Calamostachys, sporangiophore attachment could vary within a plant, with Palaeostachya-like sporangiophores occurring in younger cones.

The number of sporangia per sporangiophore might prove to be a more reliable taxonomic character but, as pointed out by Gastaldo (1981a) this can be difficult to use in practice unless exceptionally well preserved fossils are available.

Since there is no clear-cut morphological separation of most of these fossil-genera, and as pointed out by Good (1975) there is no correlation with the fossil-genera of vegetative structures in either adpressions or anatomically preserved fossils (see also Crookall, 1969, p. 621), there could be a case for combining at least some of these fossils 
into a single genus. However, for the time being we have retained the traditionally used fossil-genera, if only because it provides a useful (if artificial) tool for grouping the cone species for taxonomic comparison. In this context, the Welsh fossils, with their axillary attachment of the sporangiophores, four sporangia per sporangiophore, and slender bracts, clearly fit within the traditional concept of Palaeostachya.

\subsection{Species nomenclature}

In some previous studies, where evidence has been found of different parts of a sphenophyte plant attached or in close association with one another, those parts have been assigned to different fossil-genera but combined with the same species epithet: for instance, Stur (1887) named vegetative shoots Asterophyllites cruciatus Stur that he believed belonged to the same plant as the stems Calamites cruciatus Sternberg. Although this is technically permitted by the regulations of the International Code of Nomenclature, it can result in ambiguity as to the circumscription of the taxa and the typification of the names. This is particularly problematic when not all of the plants that produced (in this case) a particular type of stem had the same type of foliage. In our view, it is safer to use different species epithets for the different fossil-species, even if we are quite confident that the parts belong to the same species of parent plant.

\section{SYSTEMATIC PALAEOBOTANY}

\section{Class EQUISETOPSIDA}

Family Calamitaceae Unger, 1840

Fossil-genus Asterophyllites Brongniart, 1828a nom. cons.

\section{Asterophyllites tayloriorum sp. nov.}

(Figs 2a-3d)

Type. Specimen BMNH (V 68601a) (Fig. 2b); South Wales Middle Coal Measures Formation (middle Westphalian Stage), Hirwaen spoil tip, near Ebbw Wales, south Wales, UK.

Derivatio nominis. Named after Cliff and Iris Taylor, who collected the specimens described in this paper.

Diagnosis. Leafy shoots with at least two orders of axes; ultimate shoots borne in whorls, each in axil of slender leaf. Ultimate shoots with whorls of four leaves borne at 1.5-2.0 mm intervals; leaves attached to stem at c. $90^{\circ}$ except near shoot apex. Leaves up to $5 \mathrm{~mm}$ long, slender, falcate to gradually tapered, adaxially curved such that distal part is about parallel to stem.

Description. Leafy shoots preserved for a length of up to $175 \mathrm{~mm}$, with at least two orders of axes (Figs 2a-2b). Penultimate axes up to 1-2 mm wide, longitudinally striate, with nodes spaced up to $30 \mathrm{~mm}$ apart in most proximal positions (Fig. 3d) progressively reducing to $6 \mathrm{~mm}$ apart in most distal part (Fig. 3a). Each node has at least 6, possibly 8 slender, gently tapered, $8-14 \mathrm{~mm}$ long leaves (Fig. 3a). Leaves usually attached at right-angles or deflected slightly abaxially, although this can sometimes be by as much as $45^{\circ}$ abaxially, or even deflected adaxially, probably due to taphonomic distortion; leaves mostly gently curved and in their most distal part they lie at $80^{\circ}$ to the axis in proximal parts of the shoot, but nearer to $30^{\circ}$ to the axis in more distal positions.

In the axil of the slender leaves each node also has 4 ultimate leafy shoots up to $15-30 \mathrm{~mm}$ long and consistently 4-5 mm wide for most of length. Ultimate leafy shoots attached at about right-angles to the penultimate axis; in the more proximal shoots they remain near to right-angles to the parent axis (Figs 3c-3d), but usually they curve quickly so that for most of their length they are at $40-50^{\circ}$ to the main axis (Figs 2a-2b); in more distal positions in the shoot the ultimate rachises become more oblique, reducing to $20-30^{\circ}$ in the most distal positions (Fig. 3a). The axes of the leafy shoots are slender, c. $0.5 \mathrm{~mm}$ wide, with whorls of four leaves borne at $2 \mathrm{~mm}$ intervals over most of their length (Figs 2e, 3e), reducing to c. $1.5 \mathrm{~mm}$ in more distal parts of the shoot (Figs 2c-2d). Leaves are up to $5 \mathrm{~mm}$ long in proximal parts of the shoot, reducing to c. $2 \mathrm{~mm}$ in more distal positions; leaves slender, falcate to gradually tapered with acute apex, usually attached to stem at near to right-angles (although sometimes at a more acute angle, especially in distal parts of shoot) and then curving rapidly such that their distal part is about parallel to the axis. In the smaller ultimate shoots, the leaves appear adpressed against the axis. Each leaf has a central vein running along its entire length.

Remarks. The Fossilium Catalogus (Jongmans, 1914; Jongmans \& Dijkstra, 1969; Dijkstra \& van Amerom, 1995) and Boureau (1964) list 134 species of Asterophyllites but most are taxonomically illegitimate. Just ten species are reasonably well documented and can be realistically compared with the Welsh material. Five species can be immediately rejected for the Welsh specimens, as they have significantly more (more than six) and larger leaves (> $5 \mathrm{~mm}$ long) in each whorl: Asterophyllites densifolius Grand'Eury, 1877, Asterophyllites discifer Leggewie \& Schonefeld, 1961, Asterophyllites equisetiformis (Schlotheim ex Sternberg) Brongniart, 1828a (= Bornia equisetiformis Schlotheim ex Sternberg, 1825), Asterophyllites gothanii Leggewie 

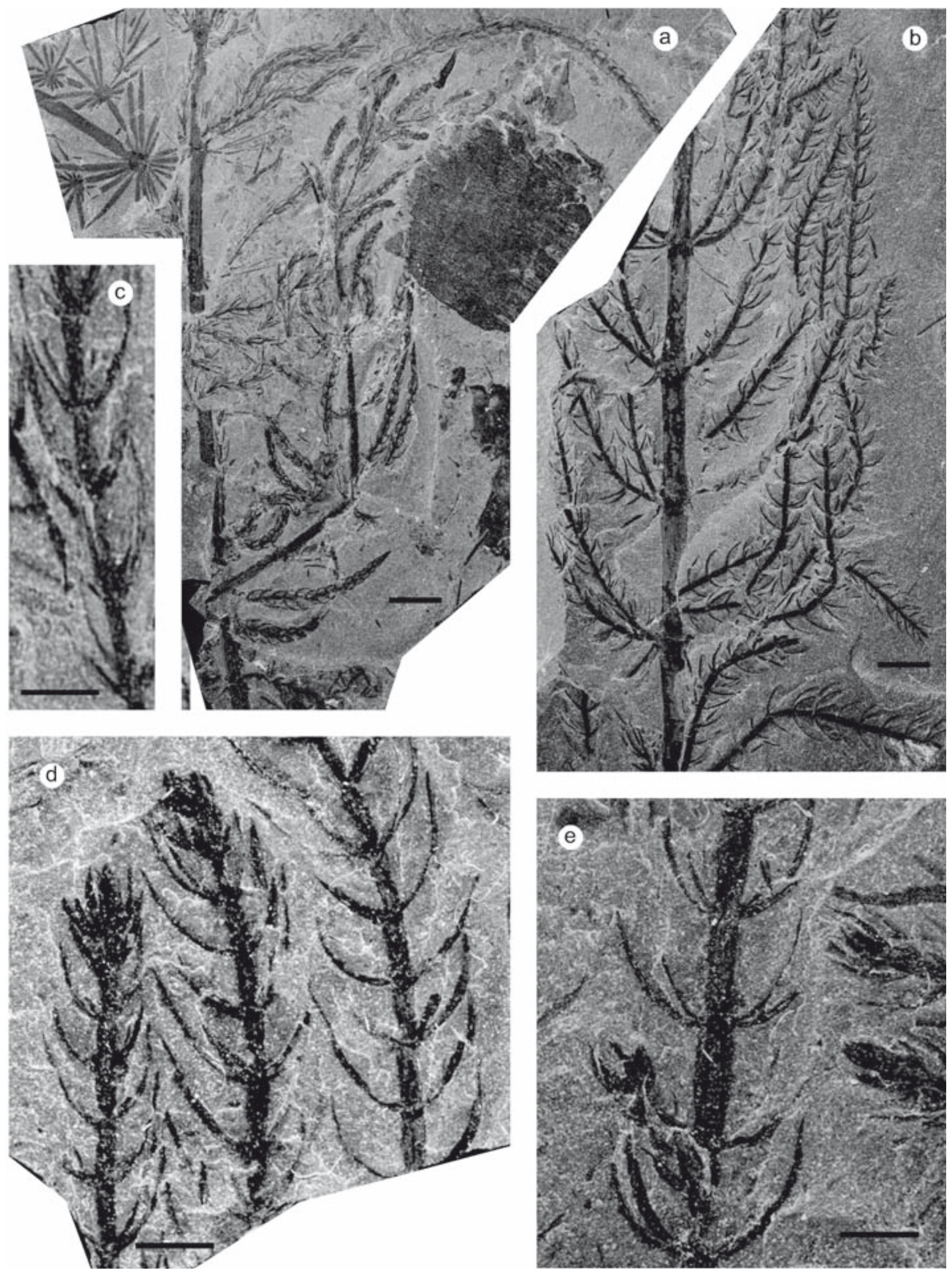
\& Schonefeld in Gothan et al., 1959, Asterophyllites longifolius (Sternberg) Brongniart, 1828b (= Bruckmannia longifolia Sternberg, 1825) and Asterophyllites tener Jongmans \& Gothan in Jongmans, 1925.

Of the five smaller leafed species, the most similar is Asterophyllites grandis (Sternberg) Lindley \& Hutton, 1832 (= Bechera grandis Sternberg, 1825), which has similar slender, falcate to gradually tapered, adaxially curved leaves, in whorls of only a few (? four). The species has not been the subject of recent study based on its type from the Radnice Member of Central Bohemia, but the illustration with the protologue (Sternberg, 1825, pl. 49, fig. 1) and the small photograph of the same specimen given by Kvaček \& Straková (1997, pl. 25, fig. 4) indicate that the leaves were rather larger than in the Welsh specimens, 5-10 mm long (see also Feistmantel, 1874, pl. 12, fig. 4; pl. 13, fig. 3, also from the Radnice Member). Moreover, Feistmantel (1874) associated rather larger cones with the Czech foliage, referred to Palaeostachya elongata (Presl) Weiss, 1876 (= Volkmannia elongata Presl, 1838 - see Němejc, 1953, for a taxonomic analysis of those cones).

The leafy shoots normally associated with the name Asterophyllites grandis, probably in error, also tend to have rather larger, usually 5-10 mm long leaves (Zeiller, 1888; Jongmans, 1911, p. 203). Moreover, unlike both the Welsh specimens and the type of $A$. grandis, they have far more leaves per whorl: 16-20 according to Zeiller (1888) and Jongmans (1911, p. 203), 8-10 according to Jongmans (1911, p. 226), Abbott (1958), Crookall (1969) and Laveine (1989). It is also of note that Zeiller (1888) described rather different cones with a Calamostachys architecture associated with the French specimens he assigned to $A$. grandis, quite different from the Palaeostachya cones associated with the Welsh leafy shoots.

Three other small-leaved Asterophyllites species lie close to the Welsh specimens: Asterophyllites charaeformis (Sternberg) Göppert in Wimmer, 1844 (= Bechera charaeformis Sternberg, 1825), Asterophyllites unguis Jongmans \& Gothan in Jongmans, 1925 and Asterophyllites lycopodioides Zeiller, 1888. All three have similar falcateshaped leaves, but those leaves tend to be smaller (usually 1-3 mm long) and there tend to be more leaves per whorl (usually five or six). A. lycopodioides can moreover be distinguished by its leaves tending to be closely adpressed to the stem, whilst $A$. unguis has very distinctive, "clawshaped" leaves. The least well-known of these smallleafed species is Asterophyllites heimansii Jongmans \& Gothan in Jongmans, 1925 but the protologue shows the type (which was of Namurian age) to be characterised by leaves with a much thicker central vein than is seen in the Welsh specimens.

There is some superficial similarity with Asterophyllites dumasii Zeiller, 1892, which has what appear to be leaves of similar size and shape, although there are usually more in each whorl (6-8). However, Kerp (1984) has shown that this species almost certainly represents Metacalamostachys Hirmer, 1927 cones where the sporangia have been lost, just leaving the bracts attached to the cone axis, and so differ from the Welsh specimens, which are clearly vegetative shoots.

The Asterophyllites specimens described in this paper are possibly conspecific with two of the syntypes of Calamites tenuifolius Ettingshausen (1854, pl. 2, figs 2-3; not fig. 1, which belongs to Asterophyllites longifolius) from the middle Westphalian Radnice Member of Central Bohemia. Although the Czech specimens are only figured as engravings, Ettingshausen described the shoots as having whorls of four small leaves and are associated with small cones of a Palaeostachya architecture. Establishing whether or not the Czech and Welsh specimens are conspecific will require further study of the former. However, Ettingshausen's epithet in combination with Asterophyllites would not come into competition for priority with A. taylorianum, as it would be an illegitimate later homonym of Asterophyllites tenuifolius (Sternberg) Brongniart, 1828b (= Schlotheimia tenuifolia Sternberg, $1821 \equiv$ Asterophyllites longifolius - see Jongmans, 1914).

Specimens figured by Josten (1991, pl. 30) as Asterophyllites grandis, from lower Westphalian strata of the Ruhr (Germany) may also be conspecific with the Welsh material. They have similar whorls of few leaves (? 2-4) of about the same size (2-4 mm long), and thus differ from true $A$. grandis, which has larger leaves and more leaves per whorl.

\section{Fossil-genus Palaeostachya Weiss, 1876 Palaeostachya wagneri sp. nov. \\ (Figs 4a-6d)}

Type. Specimen BMNH (V 68607) (Figs 4c, 4e); South Wales Middle Coal Measures Formation (middle Westphalian Stage), Hirwaen spoil tip, near Ebbw Wales, south Wales, UK.

Derivatio nominis. Named after Prof. Bob Wagner in honour of his extensive contribution to Palaeozoic palaeobotany and stratigraphy.

Figure 2. Asterophyllites tayloriorum Cleal \& Shute, sp. nov; South Wales Middle Coal Measures Formation (middle Westphalian Stage), Hirwaen spoil tip, near Ebbw Wales, south Wales, UK. a, c) BMNH (V 68606). b) BMNH (V 68601a) (holotype). d, e) BMNH (V 68605) (enlargements of part of Fig. 3a). Scale bars $=10 \mathrm{~mm}(\mathbf{a}, \mathbf{b})$ or $5 \mathrm{~mm}(\mathbf{c}, \mathbf{d}, \mathbf{e})$. 

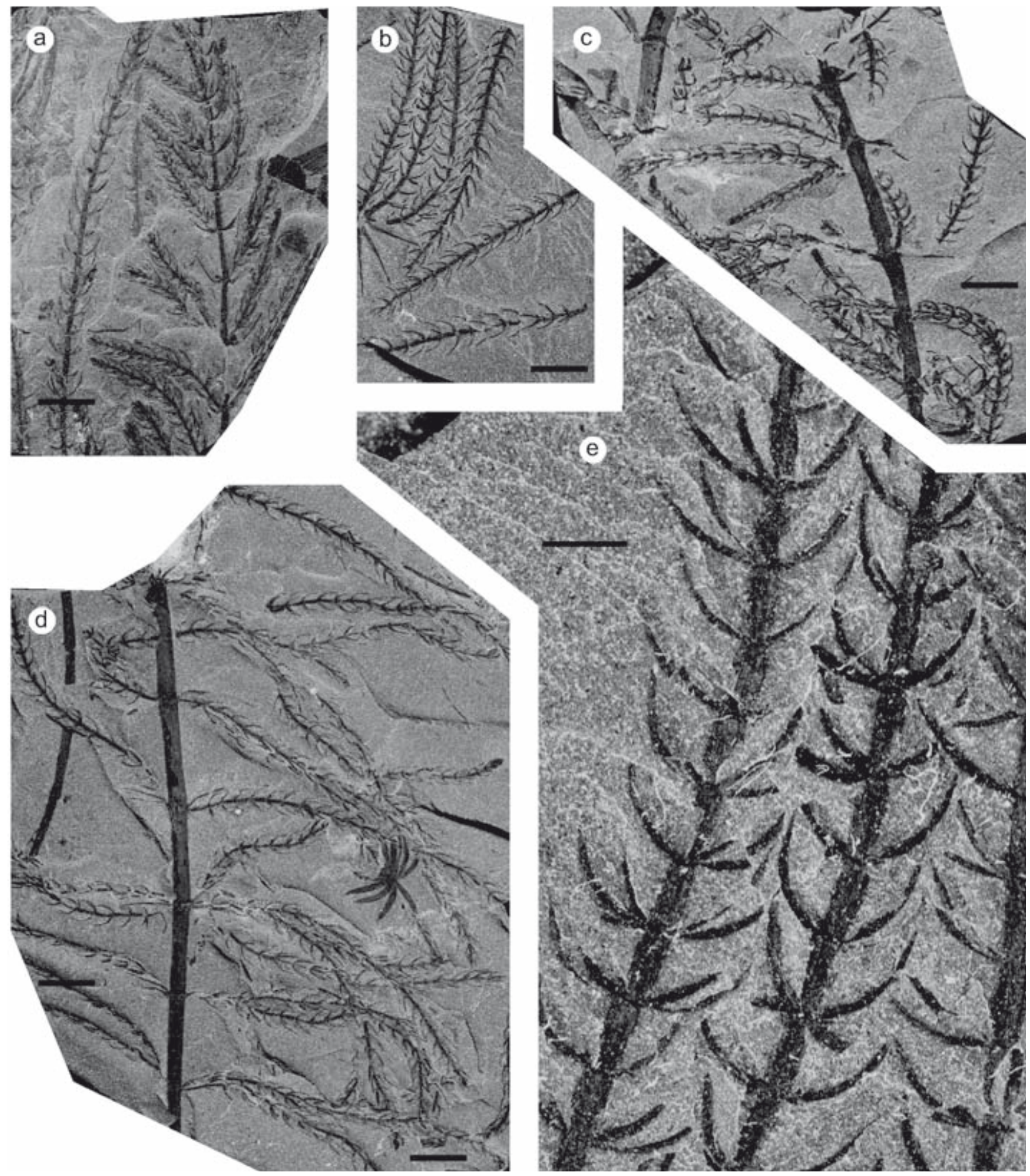

Figure 3. Asterophyllites tayloriorum Cleal \& Shute, sp. nov; South Wales Middle Coal Measures Formation (middle Westphalian Stage), Hirwaen spoil tip, near Ebbw Wales, south Wales, UK. a) BMNH (V 68605). b, e) BMNH (V 68603). c) BMNH (V 68604). d) BMNH (V 68602). Scale bars $=10 \mathrm{~mm}(\mathbf{a}, \mathbf{b}, \mathbf{c}, \mathbf{d})$ or $5 \mathrm{~mm}(\mathbf{e})$. 

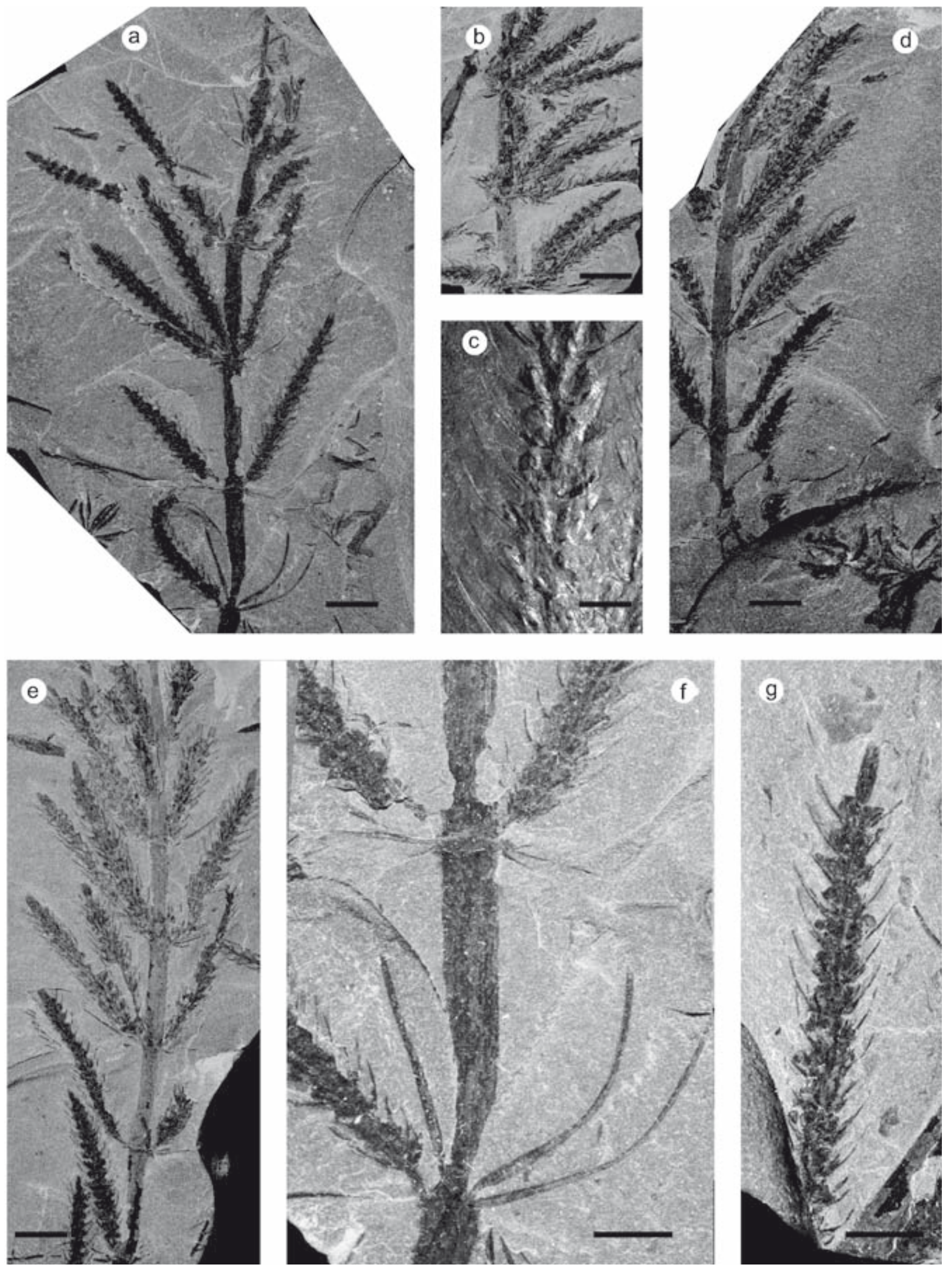

Figure 4. Palaeostachya wagneri Cleal \& Shute, sp. nov; South Wales Middle Coal Measures Formation (middle Westphalian Stage), Hirwaen spoil tip, near Ebbw Wales, south Wales, UK. a, f) BMNH (V 68612). b) BMNH (V 68608). c, e) BMNH (V 68607). d) BMNH (V 68609). g) BMNH (V 68611). Scale bars $=10 \mathrm{~mm}$ (a, b, d, e), $5 \mathrm{~mm}$ (f, g) or 2 mm (c). 
Diagnosis. Slender shoots bearing cones in whorls of four, each cone attached to axil of slender leaf. Cones attached at $70-90^{\circ}$ to stem by $2-3 \mathrm{~mm}$ long pedicel; pedicel curved so cones lie at c. $20-45^{\circ}$ to the stem. Cones $25-$ $35 \mathrm{~mm}$ long, 5-7 mm wide, parallel-sided, terminated by tuft of 3-4 mm long, distally-extending bracts that lack sporangiophores. Each cone has 10-15 whorls of four bracts spaced at 1.5-2.0 mm intervals; bracts typically 4-5 $\mathrm{mm}$ long, c. 0.1-0.2 mm wide, attached at near to rightangles to stem, but then arch gradually so are usually $35-55^{\circ}$ to the stem in distal part. Axil of each bract bears peltate sporangiophore with four elongate, rounded sporangia, $0.7 \mathrm{~m}$ long, $0.4 \mathrm{~mm}$ wide.

Description. Cone-bearing shoots up to $150 \mathrm{~mm}$ long (Figs 4a-4b, 4d-4e, 5). Main axis parallel-sided for most of length, 3-4 mm wide, finely longitudinally striate. Nodes spaced typically $20 \mathrm{~mm}$ apart along main axis, occasionally up to $40 \mathrm{~mm}$ in the proximal part of a shoot and as little as $15 \mathrm{~mm}$ in more distal parts of axis. Each node has apparently four cones (although only two or three are usually visible in the fossil: Figs $4 \mathrm{a}, 4 \mathrm{~d}$ ) together with slender leaves with acute apex, c. 10-20 mm long, c. $0.2-0.5 \mathrm{~mm}$ wide (Figs 4f, 5). At least 4 leaves per whorl, attached at $50-90^{\circ}$ to axis, directed in an abaxial direction, but then curve adaxially so in their distal part they lie at about right-angles to axis. The cones are typically attached at $70-90^{\circ}$ to the axis (sometimes apparently at a more acute angle but this is probably due to taphonomic distortion). The very short pedicel, 2-3 $\mathrm{mm}$ long, rapidly curves so that for most of their length the cones lie at c. $20-45^{\circ}$ to the stem. Cones typically 25-35 mm long, 5-7 mm wide, parallel-sided for most of their length except in their distalmost part. Whorls of bracts spaced at 1.5-2.0 mm intervals; at least 4 bracts in each whorl (exact number impossible to determine) (Fig. 6). Bracts very slender (c. 0.1-0.2 mm wide), 4-5 $\mathrm{mm}$ long for most of cone length, reducing to $\mathrm{c}$. $3 \mathrm{~mm}$ long in distal part. Bracts attached at near to right-
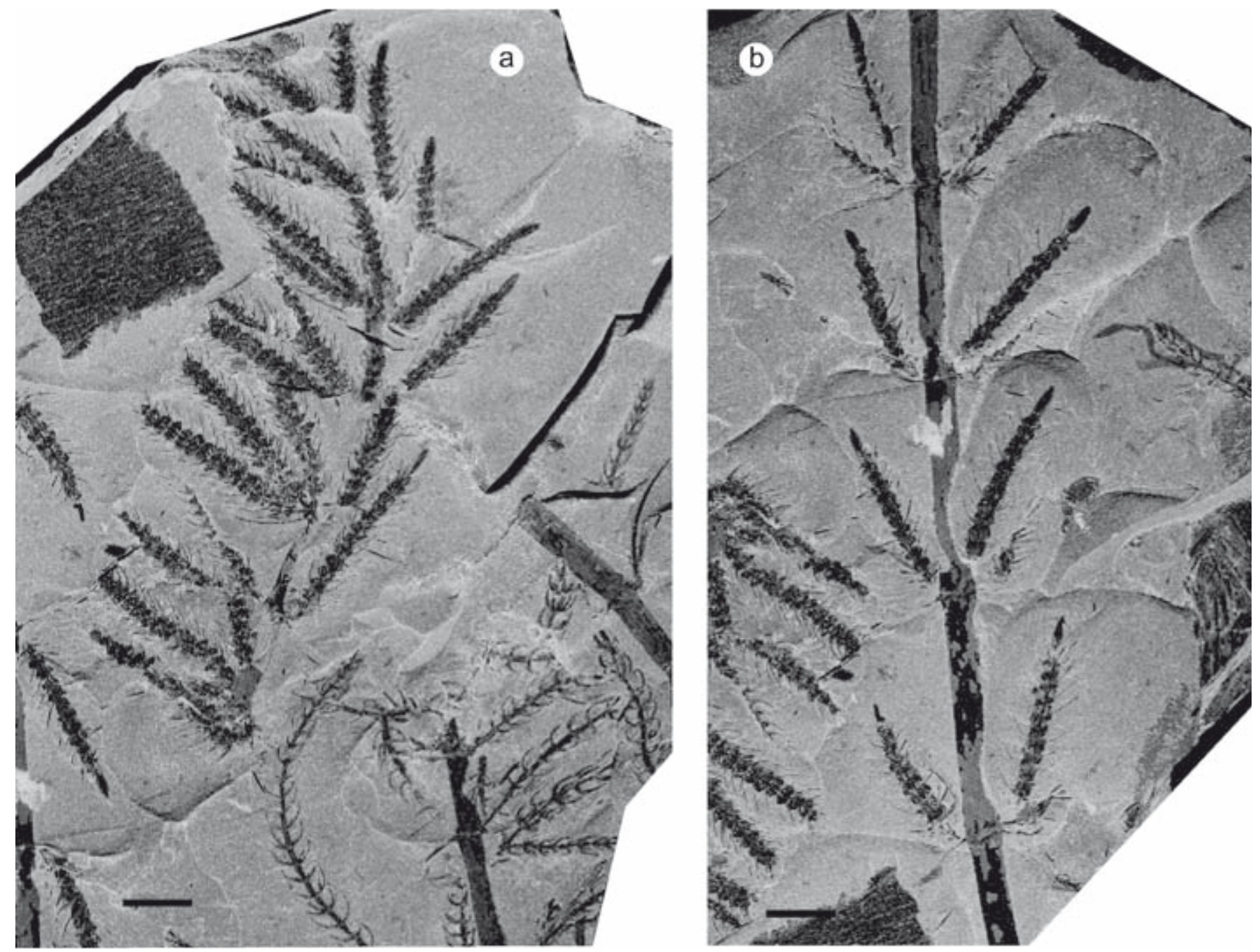

Figure 5. Palaeostachya wagneri Cleal \& Shute, sp. nov; South Wales Middle Coal Measures Formation (middle Westphalian Stage), Hirwaen spoil tip, near Ebbw Wales, south Wales, UK. a, b) BMNH (V 68610). Scale bar $=10 \mathrm{~mm}$. 
angles to cone-axis, but then arch broadly so in their distalmost part they are usually $35-55^{\circ}$ to cone-axis (Figs $4 \mathrm{c}$, $4 \mathrm{~g}, 6)$. Round to sub-obconical structures $0.5-1.5 \mathrm{~mm}$ in size, presumably the remains of sporangiophores, appear to lie in the axil between the bract and stem (Figs 4c, 6b$6 \mathrm{c})$; in most cases their structure cannot be resolved, but occasionally a pedicel can be seen attached to the axil of the bract, and this is terminated by a flattened (?peltate) head with up to 4 elongate rounded bodies (?sporangia) $0.7 \mathrm{~m}$ long, $0.4 \mathrm{~mm}$ wide, directed back towards cone axis. There are 10-15 sporangiophore/bract whorls per cone. The distal-most part of the cone bears a tuft of 3-4 $\mathrm{mm}$ long bracts apparently without sporangiophores that lie approximately parallel to the cone-axis.

Remarks. Twenty-six fossil-species of Palaeostachya are listed in the Fossilium Catalogus (Jongmans, 1922; Jongmans \& Dijkstra, 1970; Dijkstra \& van Amerom, 1996), and a further three were described by Abbott (1968) and one by Gastaldo (1981a). The diagnostic characters of the 21 of the best documented of these species are summarised by Gastaldo (1981a, table 1).

Of the species that are based on adpressions types, most are much larger and have more bracts/sporangiophores per whorl than the Welsh cones. There are three species in which the cones of comparable overall size and internode length.

Palaeostachya trabeculata Abbott, 1968. According to Abbott (1968) there are more (10) bracts/sporangiophores per whorl than in the Welsh specimens. Also the bracts appear to be straighter for more of their length, only curving in their most distal part (although this could be partly a function of the maturity of the cones).

Palaeostachya paucibracteata Sandberger ex Sterzel, 1907 ("Palaeostachya paucibracteata" Sandberger, 1890 nomen nudum). None of the published syntypes, which are very latest Carboniferous or early Permian in age (Sandberger, 1866, pl. 5, figs 4-5; Sterzel, 1907, pl. 68, figs 3, 5) are particularly diagnostic, and Jongmans (1911) stated that some key characters are unknown; in particular the number of bracts/sporangiophores per whorl and the mode of attachment of the cones to the axis. The species name is for the time being probably best regarded as unusable.

Palaeostachya acicularis Matthew, 1906. Although of similar length, the cones are rather wider and the internode distance greater; also the number of bracts/sporangiophores per whorl is unknown.
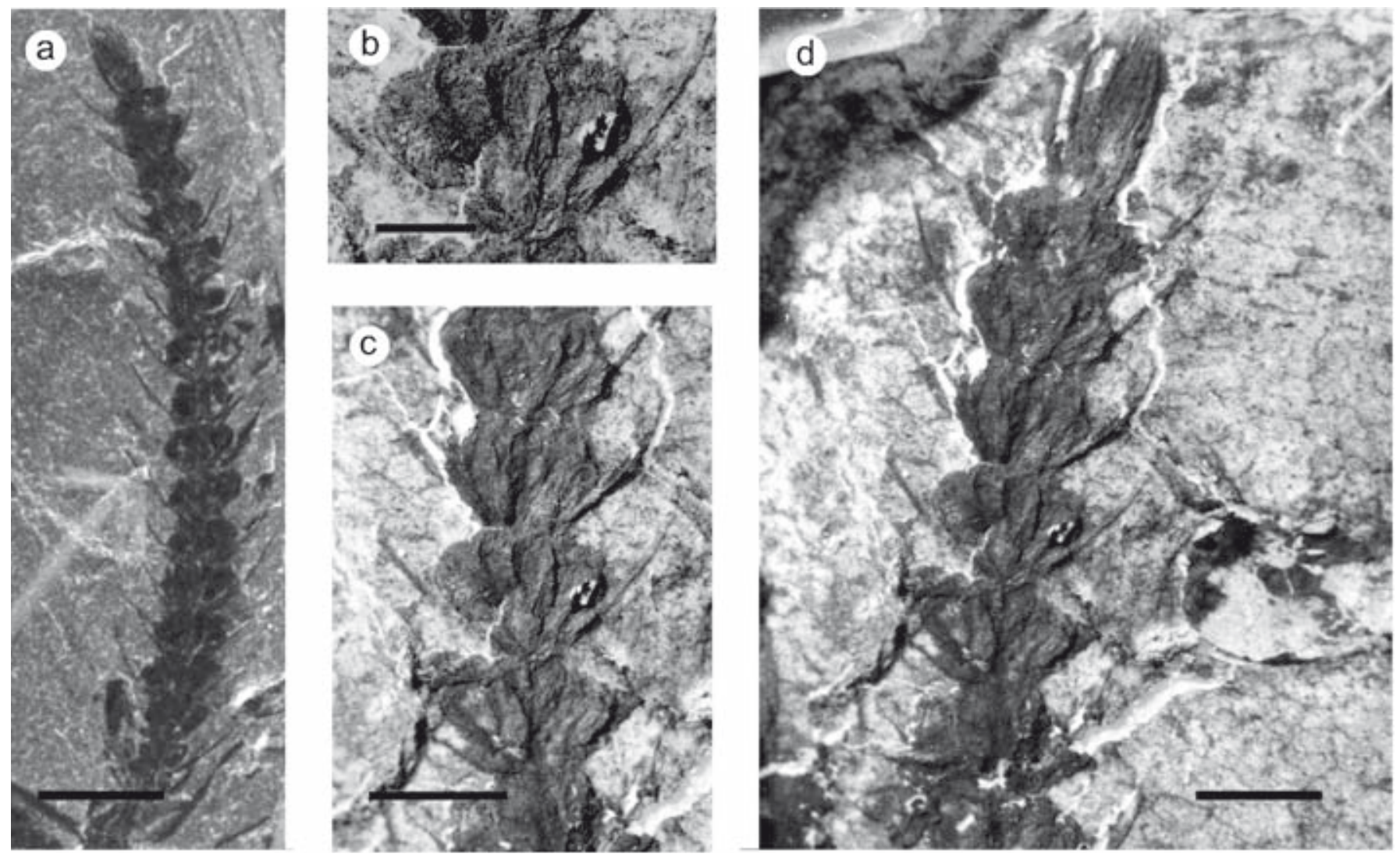

Figure 6. Palaeostachya wagneri Cleal \& Shute, sp. nov; South Wales Middle Coal Measures Formation (middle Westphalian Stage), Hirwaen spoil tip, near Ebbw Wales, south Wales, UK; BMNH (P6). a) Cone still on rock, prior to transfer. b-d) (V 68613) transfers of cone. Scale bars $=10 \mathrm{~mm}(\mathbf{a}), 2 \mathrm{~mm}$ (b), $5 \mathrm{~mm}$ (c, d). 
The only species which appears to approach the Welsh specimens in the small number of bracts/ sporangiophores per whorl (6-10 according to Gastaldo, 1981a) is Palaeostachya ovalis (Lesquereux) Abbott, 1958 (= Asterophyllites ovalis Lesquereux, 1858). However, the cones preserved in the type, photographically refigured by Abbott (1968, pl. 2 figs 2, 3) are substantially larger, more than $70 \mathrm{~mm}$ long and $10 \mathrm{~mm}$ wide.

Of the species based on anatomically preserved types, the Welsh cones overlap with the lower end of the size range of Palaeostachya pedunculata Williamson ex Weiss, 1884. However, the latter are mostly much larger (up to $70 \mathrm{~mm}$ long), have more bracts/sporangiophores per whorl, and in the type (Williamson, 1874, pl. 5 fig. 32) the cones are borne on a $10 \mathrm{~mm}$ long peduncle. The types of Palaeostachya andrewsii Baxter, 1955 is also of similar size to the Welsh cones but again have far more bracts/ sporangiophores per whorl (18-30).

\section{DISCUSSION}

The plant fossils described in this paper represent vegetative and cone-bearing shoots that, although not in direct organic connection, were almost certainly parts of the same fossil plant species. The vegetative and conebearing shoots occur in close association with one another (e.g., Fig. 5a), and the bracts and leaves are of similar size and shape. In a case such as this, we are faced with the decision as to whether to combine the fossil-taxa for the two plant parts, thereby producing a compound fossiltaxon that begins to resemble a taxon of whole organisms, or do we retain the pragmatism of giving names to the different parts?

If we choose the first alternative then, following the $I C N$, that genus would be referred to by the earliest published name whose type could confidently be included within the circumscription of the fossil-taxon, irrespective of which plant part it represented. The problem is that such a move would be based on a subjective assumption about the relationship between the plant parts in other members of those fossil-taxa, which could never be proved to be correct in all instances. Nevertheless, it could in some cases be argued to deliver more systematic clarity than not, and any relevant fossil-taxa where the evidence of attachment or association is absent or ambiguous could be referred to using open nomenclature (e.g., "cf." or "?" - see Matthews, 1973; Bengston, 1988).

The key question would clearly be, how confident were we that all plants with, say, a particular type of foliage also had that type of cone? What if we have only a few examples of such attachment or co-occurrence? By combining the fossil-genera we may be unjustifiably imposing assumptions of systematic position on a large number of fossil-species, unsupported by empirical evidence. One solution would be to create a separate fossilgenus for the species where their foliage and cones have been confidently linked, leaving the less well-understood species in their original fossil-genera. But what should the new genus be named? A new generic name could be established based on a type showing the link between the foliage and cones. However, if the type of one of the preexisting names proved also to belong to the new genus, then that name would have to take precedence. In the above quoted example, if a genus were to be created to accommodate the Annularia spinulosa / Calamostachys tuberculata complex, as A. spinulosa is also the type of Annularia Sternberg, 1821, Annularia would have to take precedence for the new genus. This would leave many of the other species that were in Annularia, but for which evidence of the associated cones is at best equivocal (e.g., Annularia sphenophylloides (Zenker) Gutbier) requiring a new generic name. This would all be perfectly legitimate within the regulatory framework of the $I C N$, but would require a raft of new combinations that would undoubtedly disrupt the taxonomic nomenclature of the group. Would the disadvantages of this disruption really be outweighed by the systematic clarity achieved by the revised nomenclature for a small number of the more completely known fossil-species?

There are also difficulties if we try to establish fossil-species for the foliage/cone complexes. For instance, leafy shoots that have been assigned to the morphologically distinctive fossil-species Asterophyllites equisetiformis (Sternberg) Brongniart have been linked with Calamostachys cones by Crookall (1969: C. germanica Weiss) and Palaeostachya cones by Barthel (2004: P. thuringiaca (Weiss) Barthel). If we established a fossil-species for both leafy shoots and cones, the legitimate name would have to be A. equisetiformis, but that name would then have to be restricted to those fossils which we were reasonably certain had the type of cone associated with the type of Asterophyllites (almost certainly C. germanica). A new name would presumably be needed for the A. equisetiformis-like foliage/Palaeostachya cone complex. And what would we do with those foliage fossils that clearly corresponded in morphology with traditional A. equisetiformis concept but for which no evidence of cones is available: we would not know in which of these foliage/cone species to place them?

Some of the nomenclatural problems inherent with such compound fossils-taxa involving different parts of the plant can be seen in the work of Stur (1887). For instance he established the species Calamites schulzii Stur based on foliage, cones and stems, the correlation of these plant parts having been based only on association. Clear emphasis was given to the morphology and branching of the stems in his description and discussion of this species, but no 
types were designated. Hirmer (1927) later created a new combination Palaeostachya schulzii (Stur) Hirmer for the cones (it should be noted that the cones are in fact clearly of the Macrostachya Schimper type); but it is in fact far from clear that these cones were in fact borne on the type of stems and leafy shoots described by Stur (1887) as $C$. schulzii; it is equally uncertain that all stems and leafy shoots of this type bore such cones. Even if we accept Stur's (1887) taxonomic treatment of $C$. schulzii, we are left with a fossil-species that can only be used for fossils in which we have attached (or at least closely associated) cones, stems and leafy shoots; given the standard of preservation of most of these plant fossils, this will only rarely occur. The result will be a fossil-species that will rarely be useable and thus of very limited value to the palaeobotanical community.

An alternative solution at the rank of genus could be simply to combine all Asterophyllites and Annularia vegetative shoots, and all Calamostachys and Palaeostachya (and possibly other) cones into a single fossil-genus. This was an implicit suggestion by Good (1975), who could find no evident correlation between the existing fossilgenera of foliage and cones, although he made no formal taxonomic revision to this effect. However, this also could present future taxonomists with difficulties. It may eventually prove possible to subdivide these fossils in a botanically meaningful way, maybe using characters such as epidermal structure that have yet to be fully utilised in this group (except by Abbott, 1958; Barthel, 2000, 2004); combining them now under one fossil-genus, only for that genus to have to be un-picked at a later date, may cause more problems than it is worth.

Given the current state of understanding of the relationship between the foliage and cones in these sphenophyte adpressions, we believe it is best to maintain the pragmatism of the status quo and keep the fossil-genera and -species separate for the two plant parts. Although the separation may have little botanical systematic significance, it at least has some utilitarian benefit for the collector and curator. However, where does this leave us when trying to undertake taxonomic diversity studies in these fossil floras? Retaining both sets of fossil-taxa will obviously inflate the organismal diversity that we are trying to determine through such studies. Cleal $(2005,2007)$ and Cleal et al. $(2012 b)$ argued that for such studies, the fossil-species for just one plant part per plant group should be counted. However, in these sphenophytes, it is not clear whether just the foliage-species or just the cone-species would give a more reliable indication of organismal taxonomic diversity. Perhaps the only way forward is to develop some sort of informal couplet-taxonomy for such studies, such as Asterophyllites tayloriorum / Palaeostachya wagneri. This clearly needs to be looked-at through a more comprehensive review of Late Palaeozoic sphenophyte adpressions taxonomy.

\section{ACKNOWLEDGEMENTS}

We dedicate this paper to Bob Wagner, in recognition of his immense contribution to Palaeozoic palaeobotanical studies. We are also deeply indebted to Cliff and Iris Taylor, who donated the specimens described in this paper to the NHM. We are grateful to Dr Peta Hayes (Department of Earth Sciences) and the Photographic Department at the NHM for providing the photographic images used in the paper; and also to the NHM library services for resources used during the historical research. Thanks also go to Arden Bashforth (Danish Natural History Museum, Copenhagen), Barry Thomas (Aberystwyth University) and Carmen Álvarez-Vázquez and John Knight (Córdoba) for constructive comments and advice on the first draft of the paper.

\section{REFERENCES}

Abbott, M.L. 1958. The American species of Asterophyllites, Annularia, and Sphenophyllum. Bulletin of American Paleontology, 38, 289-390.

Abbott, M.L. 1968. Lycopsid stems and roots and sphenopsid fructifications and stems from the Upper Freeport Coal of southeastern Ohio. Palaeontographica Americana, 6, 5-49.

Barthel, M. 2000. Annularia stellata oder Annularia spinulosa? Veröffentlichungen Naturkundemuseum Erfurt, 19, 37-42.

Barthel, M. 2004. Die Rotliegendflora des Thüringer Waldes. Teil 2: Calamiten und Lepidophyten. Veröffentlichungen des naturhistorisches Museums Schleusingen, 19, 19-48.

Bateman, R.M. \& DiMichele, W.A. 1994. Heterospory: the most iterative key innovation in the evolutionary history of the Plant Kingdom. Biological Reviews, 69, 345-417; doi:10.1111/j.1469-185X.1994.tb01276.x.

Baxter, R.W. 1955. Palaeostachya andrewsii, a new species of calamitean cone from the American Carboniferous. American Journal of Botany, 42, 342-351.

Baxter, R.W. 1963. Calamocarpon insignis, a new genus of heterosporous, petrified calamitean cones from the American Carboniferous. American Journal of Botany, 50, 469-476.

Bek, J. \& Opluštil, S. 1998. Some lycopsid, sphenopsid and pteropsid fructifications and their miospores from the Upper Carboniferous basins of the Bohemian Massif. Palaeontographica, Abt. B, 248, 127-161.

Bengtson, P. 1988. Open nomenclature. Palaeontology, 31, 223-227.

Boureau, E. 1964. Traité de Paléobotanique. Tome III. Sphenophyta, Noeggerathiophyta. Masson et Cie Éditeurs, Paris.

Brongniart, A. 1822. Sur la classification et la distribution des végétaux fossiles en général, et sur ceux des terrains de 
sediment supérieur en particulier. Mémoires du Museum d'Histoire Naturelle, Paris, 8, 203-240.

Brongniart, A. 1828a. Prodrome d'une histoire des végétaux fossiles. F.G. Levrault, Strasbourg.

Brongniart, A. 1828b. Histoire des végétaux fossiles, 1 (1-2). G. Dufour \& E. d'Ocagne, Éditeurs.

Christenhusz, M.J. \& Chase, M.W. 2014. Trends and concepts in fern classification. Annals of Botany, 113, 571-594; doi:10.1093/aob/mct299.

Cleal, C.J. 1993. Pteridophyta. In: The Fossil Record 2 (ed. Benton, M.J.). Chapman \& Hall, London, 779-794.

Cleal, C.J. 2005. The Westphalian macrofloral record from the cratonic central Pennines Basin, UK. Zeitschrift der Deutschen Gesellschaft für Geowissenschaften, 156, 387-410.

Cleal, C.J. 2007. The Westphalian-Stephanian macrofloral record from the South Wales Coalfield. Geological Magazine, 144, 465-486.

Cleal, C.J. \& Thomas, B.A. 2010. Botanical nomenclature and plant fossils. Taxon, 59, 261-268.

Cleal, C.J., Thomas, B.A., Konijnenburg-van Cittert, J.H.A. van \& Zijlstra, G. 2012a. Proposal to change the authorship of Calamites, nom. cons. (fossil, Sphenopsida) and to delete Calamitis, nom. rej. Taxon, 61, 884-885.

Cleal, C.J., Uhl, D., Cascales-Miñana, B., Thomas, B.A., Bashforth, A.R., King, S.C. \& Zodrow, E.L. 2012b. Plant biodiversity changes in Carboniferous tropical wetlands. Earth-Science Reviews, 114, 124-155; doi:10.1016/j. earscirev.2012.05.004.

Crabb, P. 2001. The use of polarised light in photography of macrofossils. Palaeontology, 44, 644-659; doi:10.1111/1475-4983.00196.

Crookall, R. 1969. Fossil plants of the Carboniferous rocks of Great Britain [Second Section]. Part 5. Memoirs of the Geological Survey of Great Britain, Palaeontology, 4, 573-792.

Dijkstra, S.J. \& Amerom, H.W.J. van 1995. Fossilium Catalogus. II: Plantae. Pars 96: Sphenophyta (1). 2. Supplement Acrobulbites - Fructibus. Kugler Publications, Amsterdam.

Dijkstra, S.J. \& Amerom, H.W.J. van 1996. Fossilium Catalogus. II: Plantae. Pars 97: Sphenophyta (2). 2. Supplement und Nachtrag Gamophyllites - Zapfen. Kugler Publications, Amsterdam.

Escapa, I.H., Axsmith, B.J., Taylor, T.N. \& Taylor, E.L. 2010. Modifications of the transfer technique for studying complex plant structures. Review of Palaeobotany and Palynology, 159, 62-68; doi:10.1016/j. revpalbo.2009.10.007.

Ettingshausen, C. von. 1854. Die Steinkohlenflora von Radnitz in Böhmen. Abhandlungen der kaiserlichköniglichen Geologischen Reichsanstalt, 2 (3), 1-74.

Feistmantel, O. 1874. Die Versteinerungen der böhmischen Kohlenablagerungen (1-3). Palaeontographica, 23, 1-156.

Gastaldo, R.A. 1981a. Palaeostachya dircei n. sp., an authigenically cemented equisetalean strobilus from the Middle Pennsylvanian of southern Illinois. American Journal of Botany, 68, 1306-1318.
Gastaldo, R.A. 1981b. Taxonomic considerations for Carboniferous coalified compression equisetalean strobili. American Journal of Botany, 68, 1319-1324.

Good, C.W. 1975. Pennsylvanian-age calamitean cones, elater-bearing spores, and associated vegetative organs. Palaeontographica, Abt. B, 153, 28-99.

Gothan, W., Leggewie, W. \& Schonenfeld, W. 1959. Die Steinkohlenflora der westlichen paralischen Carbonreviere Deutschlands. Lieferung 6. Beihefte Geologisches Jahrbuch, 36, 1-90.

Grand'Eury, F.C. 1877. Mémoire sur la flore carbonifère du département de la Loire et du centre de la France: étudiée aux trois points de vue, botanique, stratigraphique et géognostique. Académie des Sciences, Paris.

Grauvogel-Stamm, L. \& Lugardon, B. 2009. Phylogeny and evolution of the horsetails: Evidence from spore wall ultrastructure. Review of Palaeobotany and Palynology, 156, 116-129; doi:10.1016/j.revpalbo.2008.10.002.

Harris, T.M. 1961. The Yorkshire Jurassic Flora (Volume 1, Thallophyta- Pteridophyta). British Museum (Natural History), London.

Hartung, W. 1933. Die Sporenverhaltnisse der Calamariaceen. Arbeiten aus dem Institut für Paläobotanik und Petrographie der Brennsteine, 3, 95-149.

Hirmer, M. 1927. Handbuch der Paläobotanik. Band 1. Oldenbourg, München and Berlin.

Jongmans, W.J. 1911. Anleitung zur Bestimmung der Karbonpflanzen West-Europas mit besonderer Berücksichtigung der in den Niederlanden und den benachbarten Länderen gefundenen oder noch zu erwartenden Arten. I Band. Thallophytae, Equisetales, Sphenophyllales. Craz \& Gerlach, Freiberg in Sachsen (Mededeelingen van de Rijksopsporing van Delfstoffen, 3).

Jongmans, W.J. 1914. Fossilium Catalogus. II: Plantae. Pars 4: Equisetales III: Asterophyllites - Calamitea. W. Junk, Berlin.

Jongmans, W.J. 1922. Fossilium Catalogus. II: Plantae. Pars 9: Equisetales VI: Equsetites - Schluss der Equisetales. W. Junk, Berlin.

Jongmans, W.J. 1925. Geologische en palaeontologische beschrijving van het Karboon der omgeving van Epen (Limb). Mededeeling van het Geologisch Bureau voor het Nederlandisch Mijngebied, 1, 3-83.

Jongmans, W.J. \& Dijkstra, S.J. 1969. Fossilium Catalogus. II: Plantae. Pars 75: Sphenophyta I. W. Junk, 's-Gravenhage.

Jongmans, W.J. \& Dijkstra, S.J. 1970. Fossilium Catalogus. II: Plantae. Pars 77: Sphenophyta III. W. Junk, 's-Gravenhage.

Josten, K.-H. 1991. Die Steinkohlen-Floren Nordwestdeutschlands. Fortschritte in der Geologie von Rheinland und Westfalen, 36, 1-434.

Kerp, J.H.F. 1984. Aspects of Permian palaeobotany and palynology. V. On the nature of Asterophyllites dumasii Zeiller, its correlation with Calamites gigas Brongniart and the problem concerning its sterile foliage. Review of Palaeobotany and Palynology, 41, 301-317; doi:10.1016/0034-6667(84)90051-4. 
Knie, N., Fischer, S., Grewe, F., Polsakiewicz, M. \& Knoop, V. 2015. Horsetails are the sister group to all other monilophytes and Marattiales are sister to leptosporangiate ferns. Molecular Phylogenetics and Evolution, 90, 140149.

Kosanke, R.M. 1955. Mazostachys - a new calamite fructification. Report of Investigations of the Illinois State Geological Survey, 180, 7-37.

Kvaček, J. \& Straková, M. 1997. Catalogue of fossil plants described in works of Kaspar M. Sternberg. National Museum, Prague.

Laveine, J.-P. 1989. Guide paléobotanique dans le terrain houiller Sarro-Lorrain. Houillères du Bassin de Lorraine, Merlebach.

Leggewie, W. \& Schonefeld, W. 1961. Die Calamariaceen der Westfal-Schichten im Ruhrkarbon. Palaeontographica, Abt. B, 109, 1-44.

Lesquereux, L. 1858. Fossil plants of the coal strata of Pennsylvania. In: Geology of Pennsylvania (ed. Rogers, H.D.). W. Blackwood \& Sons, Edinburgh and London, and J.B. Lippincott \& Co., Philadelphia, 835-884.

Lindley, J. \& Hutton, W. 1832. The fossil flora of Great Britain. Volume 1 (Part 2). W.J. Ridgeway and Sons, London, 49-166.

Matthew, G.F. 1906. A review of the flora of the Little River Group. Proceedings and Transactions of the Royal Society of Canada, Second Series. Section 4, 12, 99-149.

Matthews, S.C. 1973. Notes on open nomenclature and on synonymy lists. Palaeontology, 16, 713-719.

McNeill, J., Barrie, F.R., Buck, W.R., Demoulin, V., Greuter, W., Hawksworth, D.L., Herendeen, P.S., Knapp, S., Marhold, K., Prado, J., Prudhomme van Reine, W.F., Smith, G.F., Wierseme, J.H. \& Turland, N.J. 2012. International Code of Nomenclature for Algae, Fungi, and Plants (Melbourne Code). Koeltze, Koenigstein (Regnum Vegetabile, 154).

Meyen, S.V. 1978. An attempt at a radical improvement of suprageneric taxonomy of fossil plants. Phyta, 1, 76-86.

Meyen, S.V. 1987. Fundamentals of Palaeobotany. Chapman and Hall, London \& New York.

Němejc, F. 1953. Taxonomical studies on the fructifications of the Calamitaceae collected in the coal districts of Central Bohemia. Sborník Národního Musea v Praze, 9 B, 3-62.

Presl, R.B. 1838. Beiträge zur Kunde vorweltlicher Pflanzen. Verhandlungen der Gesellschaft des Vaterländischen Museums in Böhmen, 16, 26-30.

Remy, R. \& Remy, W. 1975. Zur Ontogenie der Sporangiophore von Calamostachys spicata var. eimeri n. var. und zur Aufstellung des Genus Schimperia n. gen. Argumenta Palaeobotanica, 4, 83-92.

Rößler, R. \& Thiele-Bourcier, M. 1999. Neue Organzusammenhänge eines Calamiten - taphonomische Beobachtungen im Oberkarbon des Saar-Nahe-Beckens. Freiberger Forschungsheft, C481, 49-61.

Rothwell, G.W.\& Taylor, T.N. 1971. Weissistachys kentuckiensis: a new name for Weissia kentuckiense Rothwell and Taylor. Botanical Gazette, 132, 371-372.
Sandberger, F. von 1866. Bemerkungen über fossile Pflanzen aus dem Rothliegenden des badischen Schwarzwaldes. Würzburger Naturwissenschaftliche Zeitschrift, 6, 74-77.

Sandberger, F. von 1890. Ueber Steinkohlenformation und Rothliegendes im Schwarzwald und deren Floren. Jahrbuch der Kaiserlich-Königlichen Geologischen Reichsanstalt, 40, 77-102.

Schimper, W.P. 1869. Traité de paléontologie végétale, 1. J.B. Baillière et Fils, Paris.

Serret, L. \& Brousmiche, C. 1987. Quelques fructifications de Calamitaceae (Arthrophytes) récoltées dans le bassin houiller sarro-lorrain (organisation-spores in situ). Palaeontographica, Abt. B, 203, 135-179.

Seward, A.C. 1898. Fossil plants for students of botany and geology. Vol. I. The University Press, Cambridge.

Sternberg, K.M. von 1821. Versuch einer geognostischbotanischen Darstellung der Flora der Vorwelt. 1 (2). F. Fleischer, Leipzig.

Sternberg, K.M. von 1825. Versuch einer geognostischbotanischen Darstellung der Flora der Vorwelt. 1 (4), Tentamen. E. Brenck's Wittwe, Regensburg.

Sterzel, J.T. 1907. Die Karbon- und Rotliegendfloren im Großherzogtum Baden. Mittelungen der Grossherzoglich Badischen Geologischen Landesanstalt, 5, 349-892.

Stur, D. 1887. Die Carbon-Flora der Schatzlarer Schichten. Abtheilung 2: Die Calamarien der Carbon-flora der Schatzlarer Schichten. Abhandlungen der KaiserlichKöniglichen Geologischen Reichsanstalt, 11 (2), 1-240.

Taylor, E.L., Taylor, T.N. \& Krings, M. 2009. Paleobotany: the biology and evolution of fossil plants. Academic Press, Burlington MA.

Thomas, B.A. 1969. A new British Carboniferous calamite cone, Paracalamostachys spadiciformis. Palaeontology, 12, 253-261.

Thomas, B.A. 1987. The use of in situ spores for defining species of dispersed spores. Review of Palaeobotany and Palynology, 51, 227-233; doi:10.1016/00346667(87)90032-7.

Thomas, B.A. 2014. In situ stems: preservation states and growth habits of the Pennsylvanian (Carboniferous) calamitaleans based upon new studies of Calamites Sternberg, 1820 in the Duckmantian at Brymbo, North Wales, UK. Palaeontology, 57, 21-36; doi:10.1111/ pala. 12045.

Thomas, H.H. 1910. On the assimilating tissue of some Coal Measure plants. Proceedings of the Cambridge Philosophical Society, 15, 413-415.

Thomas, H.H. 1911. On the leaves of Calamites (Calamocladus section). Philosophical Transactions of the Royal Society of London. Series B, 202, 51-92.

Unger, F. 1840. Abhandlung über die Struktur des Calamites und ihre Rangordnung im Gewächsreiche. Flora, 2, 654-662.

Vogellehner, D. 1967. Möglichkeiten einer regelmässen Stabilisierung der Nomenklatur karbonischen Pflanzen. Taxon, 16, 124-129.

Walton, J. 1923. On a new method of investigating fossil plant impressions of incrustations. Annals of Botany, New Series, 37, 379-391. 
Walton, J. 1936. On the factors which influence the external form of fossil plants; with descriptions of the foliage of some species of the Palaeozoic equisetalean genus Annularia Sternberg. Philosophical Transactions of the Royal Society of London, Series B, 226, 219-237.

Watson, J. 1983. Two Wealden species of Equisetum found in situ. Acta Palaeontologica Polonica, 28, 265-269.

Weiss, C.E. 1876. Steinkohlen-Calamarien, mit besonderer Berücksichtigung ihrer Fructificationen. Abhandlungen zur geologischen Spezialkarte von Preussen und den Thuringischen Staaten, 2 (1), 1-149.

Weiss, C.E. 1884. Steinkohlen-Calamarien. II. Abhandlungen zur geologischen Spezialkarte von Preussen und den Thuringischen Staaten, 5 (2), 1-204.

Williamson, W.C. 1874. On the organization of the fossil plants of the Coal-measures - Part V. Asterophyllites. Philosophical Transactions of the Royal Society of London, Series B, 164, 41-81.
Wimmer, F. 1844. Flora von Schlesien, preussischen und österreichischen Antheils. Zweiter Band. F. Hirt, Breslau.

Zeiller, R. 1888. Bassin houiller de Valenciennes. Description de la flore fossile. Études des Gîtes Mineraux de la France, Paris.

Zeiller, R. 1892. Bassin Houiller et Permien de Brive. II. Flore Fossile. Études des Gîtes Minéraux de la France, Ministère des Travaux Publics, 1-132.

Zeiller, R. 1896. Sur la flore des depôts houillers d'Asie Mineure et sur la présence, dans cette flore, du genre Phyllotheca. Compte rendu de l'Académie des Sciences, Paris, 120, 1228-1231.

Zeiller, R. 1899. Étude sur la flore fossile du basin houiller d'Héraclée (Asie Mineure). Mémoires de la Société Géologique de France, Paléontologie, 21, 1-91. 